\title{
Implementasi Student Centered Learning (SCL) Materi Olimpiade Sains Nasional (OSN) Kebumian Di SMA Negeri 8 Gowa, Sulawesi Selatan
}

\author{
Ulva Ria Irfan*, Ilham Alimuddin, Meutia Farida, Adi Maulana, Asri Jaya, \\ Haerany Sirajuddin, Adi Tonggiroh, Busthan Azikin, Sahabuddin \\ Departemen Teknik Geologi, Fakultas Teknik, Universitas Hasanuddin \\ ulvairfan@unhas.ac.id*
}

\begin{abstract}
Abstrak
Perkembangan keilmuan mata pelajaran geografi di tingkat sekolah menengah berdampak pada materi pengetahuan tentang geologi antara lain batuan dan proses pembentukannya, asal-usul bumi, hingga bagaimana merencanakan tata kota dalam perangkat sistem informasi geografis. Pada umumnya buku geografi mengacu pada kurikulum internasional earth science, sehingga sangat berat bagi siswa SMA untuk memahaminya. Permasalahan utama yang diungkap oleh guru dan siswa yang berminat dalam OSN bidang kebumian adalah materi yang diperlombakan cukup kompleks. Permasalahan dasar geologi, tata ruang dan kebencanaan menjadi issue nasional bahkan global. Melalui kegiatan Program Pengabdian Masyarakat, Fakultas Teknik dalam hal ini diwakili oleh tim dosen dari Program Studi Teknik Geologi menawarkan metode Student Centered Learning untuk memudahkan pemahaman materi Olimpiade Sains Nasional bidang Kebumian. Selain itu dapat pula menumbuhkan motivasi dan daya saing untuk mengikuti kompetisi, khususnya kepada siswa SMA Negeri 8 Gowa. Tujuan kegiatan pengabdian kepada masyarakat ini adalah untuk: a) Memberikan pengetahuan dasar geologi sebagai bagian dari ilmu kebumian; b) Memberikan pengetahuan geologi Indonesia; c) Memberikan kisi-kisi materi yang diujikan dalam olimpiade sains nasional kebumian; d) Memberikan praktek identifikasi mineral dan batuan, struktur geologi, fosil, dan pembacaan peta topografi.
\end{abstract}

Kata Kunci: Pengabdian masyarakat; Geologi dasar; Kebumian; Student Centered Learning; Geografi.

\section{Pendahuluan}

Program Pengabdian kepada Masyarakat Tahun 2019 dilaksanakan di SMA Negeri 8 Gowa, merupakan kelanjutan dari Program Iptek bagi Masyarakat (IbM) yang telah dilaksanakan oleh LP2M Unhas secara berkesinambungan sejak Tahun 2014 di Pare-Pare, Sinjai, Makassar dan Watampone (Gambar 1). Salah satu hal yang membanggakan bahwa dua peserta OSN bidang kebumian tingkat SMA yang mewakili Sulawesi Selatan pada Tahun 2017 berasal dari wilayah Kota Pare-Pare.

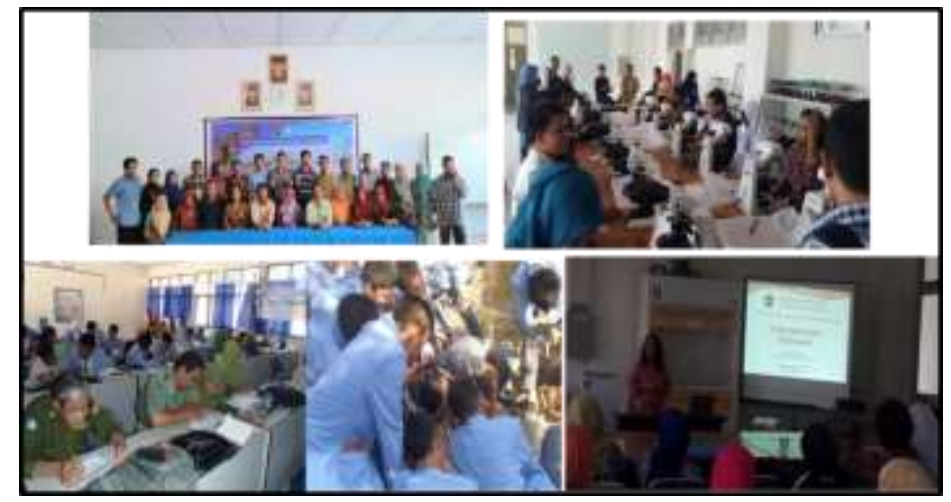

Gambar 1. Aktifitas Pelatihan Bagi Guru Geografi Tingkat SMA Di Kota Pare-Pare, Makassar, Bone Dan Sinjai 
Program Iptek bagi Masyarakat (IbM) yang telah dilaksanakan berupa kegiatan "Pelatihan Dasar Geologi dan Aplikasinya bagi Guru-Guru Geografi Tingkat SMA". Kelompok Guru-Guru Geografi yang terbentuk di Kabupaten/Kota yang selama ini menjadi mitra pada kegiatan Pengabdian kepada Masyarakat sejak Tahun 2014. Harapan dari mitra terhadap kegiatan ini adalah dijadikan agenda tahunan yang dilaksanakan paling tidak dua kali dalam setahun. Atas dasar tersebut, pada Tahun 2019 ini, Departemen Teknik Geologi Unhas bermitra dengan SMA Negeri 8 Gowa yang lokasinya sekitar 850meter dari Kampus Teknik Unhas di Gowa. Keberadaan kampus Unhas di Gowa diharapkan dapat berkontribusi untuk peningkatan kapasitas pendidikan dasar di Kabupaten Gowa, yang salah satunya melalui mitra dengan Sekolah Menengah Atas (SMA).

Dinas Pendidikan Provinsi Sulawesi Selatan merupakan bagian dari penyelenggara Olimpiade Sains Nasional (OSN). Kegiatan OSN merupakan agenda tahunan yang diselenggarakan oleh Direktorat Pembinaan SMA, Direktorat Jenderal Pendidikan Dasar dan Menengah, Kementerian Pendidikan dan Kebudayaan. Salah satu bidang keilmuan dalam OSN adalah Kebumian yang dibina oleh guru-guru geografi di tingkat SMA. Kontribusi mitra dalam kegiatan ini sangat penting dalam memfasilitasi, mengkordinasikan dan memberi motivasi kepada guru-guru geografi dan siswa untuk mempersiapkan diri mengikuti kompetisi nasional.

Pengetahuan dasar geologi sangat diperlukan untuk memahami materi yang kompleks pada ajang olimpiade sains nasional kebumian. Metode pembelajaran Student Centered Learning yang selama ini diterapkan pada mahasiswa di Fakultas Teknik Unhas, dapat diimplementasikan kepada siswa tingkat SMA. Sebagai contoh untuk mengidentifikasi mineral dan batuan, harus menggunakan pancaindera untuk membedakan warna, merasakan tingkat kekerasan, dan sebagainya.

Berdasarkan ulasan di atas dan melihat fenomena yang berkembang di masyarakat khususnya di kalangan siswa dan guru di Sekolah Menengah Atas, maka dapat disimpulkan permasalahan yang dialami oleh Mitra adalah sebagai berikut:

1. Ilmu Kebumian sangat berat dipahami oleh siswa karena buku panduan yang mereka gunakan berbasis earth science dari penulis-penulis asing.

2. Guru Geografi sebagai tenaga pendidik selaku fasilitator dalam kelas tidak mempelajari secara detail mengenai ilmu kebumian di perguruan tinggi.

3. Pelajaran Geografi tidak disajikan untuk kelompok IPA, sedangkan dalam ajang Olimpiade Sains Nasional diikuti oleh siswa dari kelompok IPA.

\section{Solusi yang Ditawarkan}

Dari berbagai permasalahan yang dihadapi oleh mitra dalam hal ini guru-guru Geografi tingkat Sekolah Menengah Atas, maka selaku pengemban Tri Dharma Perguruan Tinggi yang salah satunya adalah kegiatan Pengabdian kepada Masyarakat, menawarkan solusi sebagai berikut:

1. Memberikan pelatihan dalam bentuk ceramah mengenai dasar-dasar Geologi, bagaimana batuan tersebut terbentuk di alam, aktivitas gunungapi (vulkanik), proses-proses sedimentologi dan ilmu dasar lainnya yang terkait dengan ilmu kebumian.

2. Pelatihan dan pengenalan sampel mineral dan batuan dan cara mendeskripsinya.

3. Pengenalan dasar-dasar Sistem Informasi Geografi baik dalam bentuk demonstrasi dan hasil layout berupa peta. 
4. Pelatihan berupa kisi-kisi soal ilmu kebumian dalam OSN.

5. Pengenalan potensi bencana geologi dan mitigasi bencana alam.

6. Diskusi dari semua permasalahan yang dihadapi mitra.

Segala upaya pelatihan tersebut di atas merupakan cara paling efektif untuk mentransfer ilmu pengetahuan dan pemahaman aplikasinya dalam ilmu geologi. Dengan demikian melalui kegiatan ini diharapkan dapat meningkatkan kapasistas guru-guru Geografi dalam membina anak didiknya. Kegiatan pelatihan ini apabila dilakukan secara berkesinambungan akan membantu pemutakhiran ilmu Geologi yang tidak mereka dapatkan di bangku kuliah dan lebih memudahkan mereka memahami materi ilmu Kebumian.

Target dari kegiatan pengabdian kepada Masyarakat ini adalah sebagai berikut:

- Peningkatan kapasitas keilmuan baik guru geografi maupun beberapa peserta anak didik.

- Menambah pemahaman guru Geografi dan anak didik tentang pentingnya ilmu kebumian seperti aspek bencana alam dan mitigasi bencana geologi.

- Para guru dan siswa lebih memahami potensi sumberdaya alam dan mineral daerah mereka termasuk kebencanaan geologinya.

\section{Metode}

Pelaksanaan implementasi Student Centered Learning (SCL) materi Olimpiade Sains Nasional (OSN) kebumian di SMA Negeri 8 Gowa, Sulawesi Selatan, dirancang sedemikian rupa dalam bentuk mekanisme rancangan kegiatan sebagai berikut:

\subsection{Identifikasi Masalah}

Identifikasi masalah dengan mempelajari dan menghimpun informasi sebanyak-banyaknya tentang permasalahan yang dihadapi oleh Mitra dalam hal ini guru-guru Geografi SMA. Setelah itu, dirumuskan judul kegiatan, dilanjutkan dengan berkomunikasi dengan pihak mitra, kemudian penyusunan rencana kegiatan Pengabdian Kepada Masyarakat.

\subsection{Rencana Kegiatan}

Rencana kegiatan pelatihan meliputi persiapan sebagai berikut:

- Departemen Teknik Geologi membuat surat penugasan kepada Tim Pelaksana Pelatihan yang terdiri dari 9 orang dosen, 5 mahasiswa, dan 2 orang tenaga laboran.

- Ketua Tim berkoordinasi dengan Dinas Pendidikan Provinsi Sulawesi Selatan untuk memberi rekomendasi kepada kepala sekolah SMA Negeri 8 Kabupaten Gowa.

- Kepala Sekolah mendata jumlah guru dan siswa, untuk membuat persiapan undangan dan materi pelatihan

- Ketua pelaksana melakukan rapat persiapan untuk pembagian tugas kepada anggota Tim, yang meliputi persiapan materi pelatihan dan persiapan pelaksanaan pelatihan.

- Merancang waktu pelaksanaan pelatihan bersama dengan guru peserta pelatihan.

\subsection{Metode atau dengan Cara Apa Kegiatan ini Dilakukan}

Pelaksanaan implementasi Student Centered Learning (SCL) materi Olimpiade Sains Nasional (OSN) kebumian di SMA Negeri 8 Gowa, diawali dengan menggunakan metode ceramah demonstrasi/ilustrasi, diskusi dan praktek langsung/kunjungan lapangan. Metode ceramah diperlukan untuk menjelaskan konsep ilmu geologi yaitu the present is the key to the past (masa 
kini adalah kunci masa lalu) atau sebaliknya. Kejadian-kejadian masa lalu dan masa kini kemudian bisa digunakan untuk menafsirkan/memprediksi kejadian di masa depan.

Metode demonstrasi dilakukan dengan memperlihatkan secara langsung tentang sistem kristal, mineral dan batuan, fosil, serta ilustrasi bencana geologi dan mitigasi bencana. Selain itu juga memperkenalkan sistem informasi geografis (SIG) untuk memahami ilmu kebumian secara terpadu.

\subsection{Pelaku kegiatan}

Pemateri adalah tenaga dosen Program Studi Teknik Geologi dari berbagai keahlian dibantu lima orang mahasiswa (asisten), dan dua orang laboran. Sedangkan peserta yang terlibat dalam kegiatan pelatihan adalah guru-guru dan siswa di SMA Negeri 8 Kabupaten Gowa, Sulawesi Selatan. Materi dalam bentuk modul, power point, peraga mineral/batuan, peraga fosil dan software GIS.

\section{Hasil dan Diskusi}

Kegiatan pengabdian masyarakat dilaksanakan di Departemen Teknik Geologi, Fakultas Teknik, Universitas Hasanuddin, Kabupaten Gowa. Untuk mengenal dan mengidentifikasi batuan dan mineral, disajikan materi dalam bentuk modul dan masing-masing satu contoh batuan dan mineral yang diidentifiaksi dalam format yang telah disediakan.

\subsection{Identifikasi Mineral}

Mineral tersusun secara alamiah oleh atom-atom dan membentuk ikatan teratur yang disebut sistem kristal. Sehingga mineral yang mempunyai warna yang sama dapat dibedakan berdasarkan sistem kristalnya, seperti mineral quartz mempunyai system kristal hexagonal dan monoclinic untuk mineral orthoclase (Gambar 2).

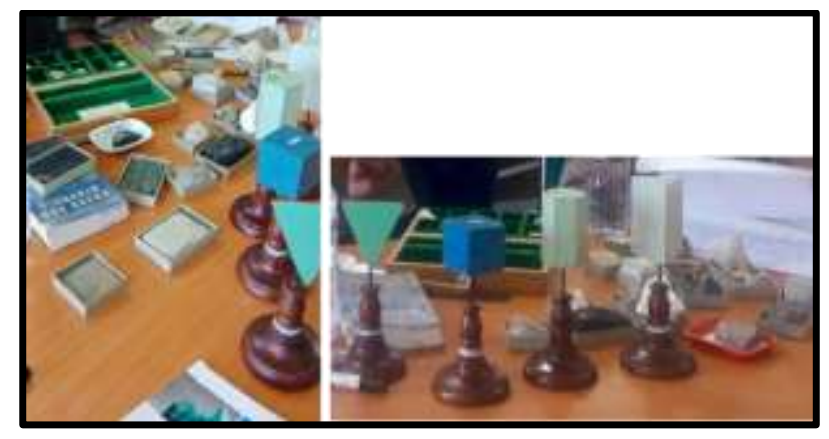

Gambar 2. Contoh Batuan Dan Peraga System Kristal Pada Laboratorium Mineral Optik Departemen Teknik Geologi.

Warna mineral adalah warna yang ditangkap oleh mata bilamana mineral tersebut terkena sinar (Gambar 3). 


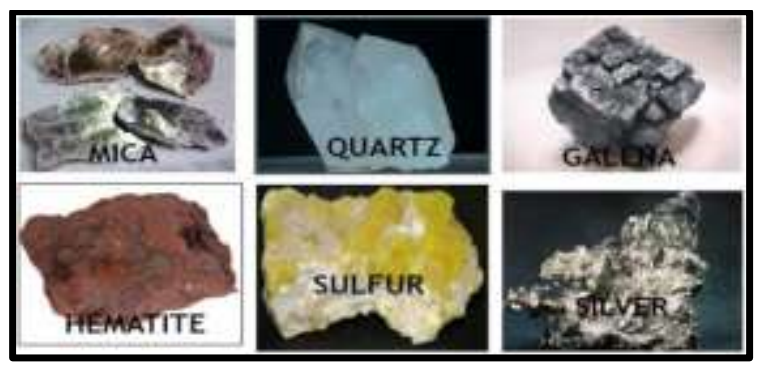

Gambar 3. Berbagai Warna Mineral

Kilap (luster) merupakan pantulan cahaya pada permukaan mineral (Gambar 4).

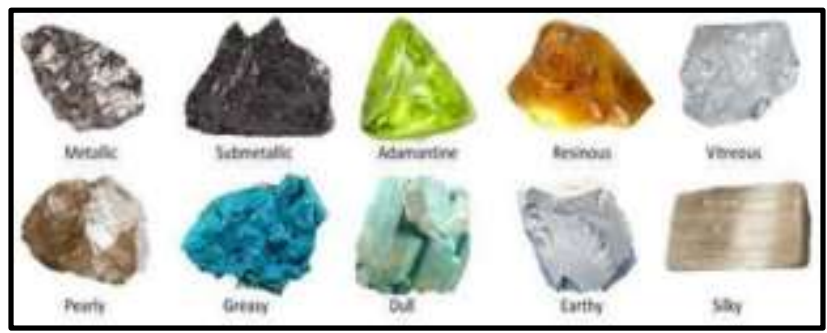

Gambar 4. Kilap Logam Dan Non Logam Pada Mineral

Streak merupakan warna mineral dalam bentuk serbuk atau hancuran, yang dapat diidentifikasi dengan menggoreskan pada porselen (Gambar 5).

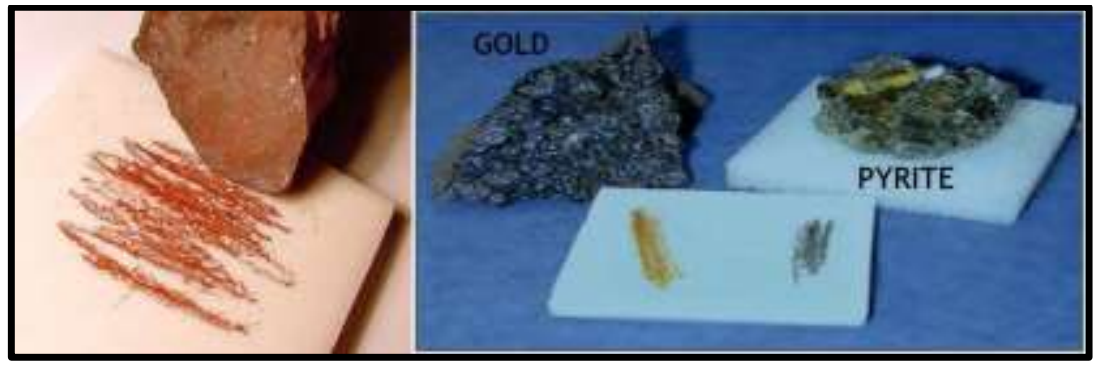

Gambar 5. Streak Atau Warna Goresan Pada Porselen

Hardness atau tingkat kekerasan mineral jika tergores, yang berdasarkan pada skala Mohs (Gambar 6).

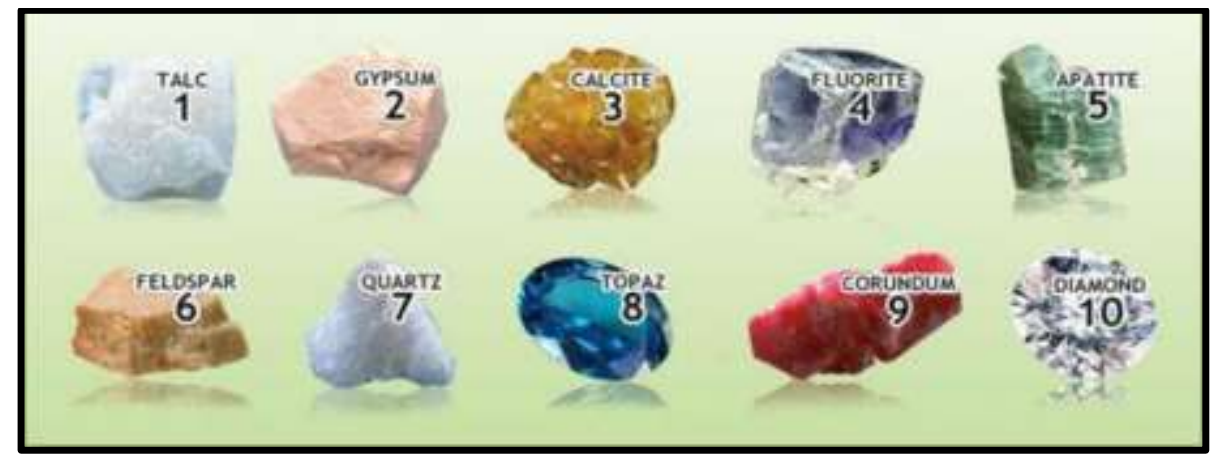

Gambar 6. Tingkat Kekerasan Mineral Berdasarkan Skala Mohs 
Cleavage atau belahan merupakan kenampakan mineral untuk membelah melalui bidang belahan yang berbentuk sejajar dengan bidang tertentu (Gambar 7).

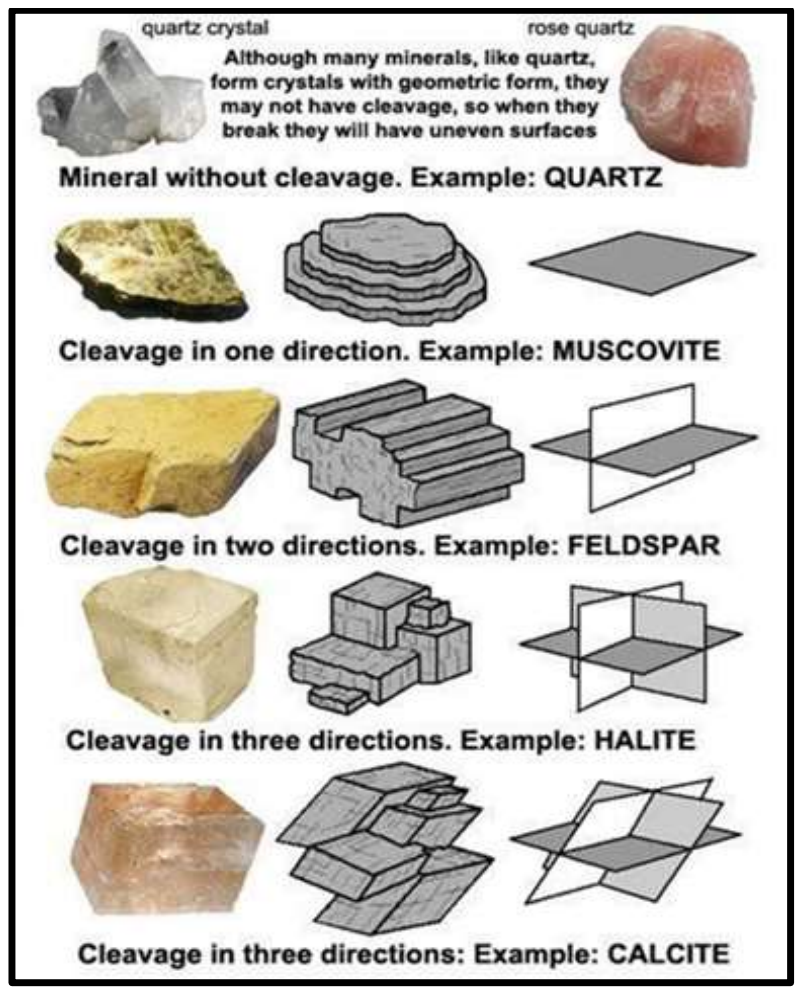

Gambar 7. Jenis arah belahan pada mineral

Untuk memudahkan mengidentifikasi berbagai jenis mineral dapat digunakan flowchat yang disajikan pada Gambar 8.

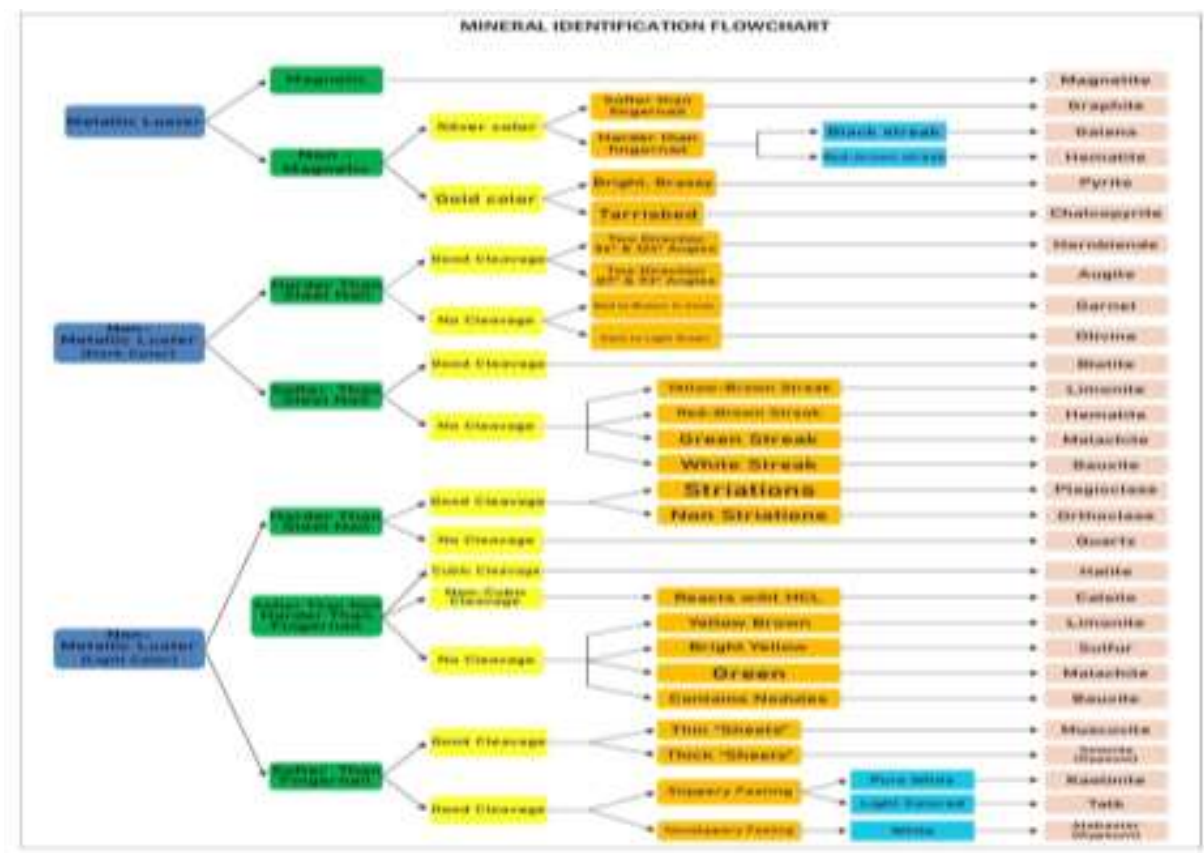

Gambar 8. Diagram Identifikasi Mineral 


\subsection{Identifikasi Batuan}

Secara genetic batuan terbagi atas tiga tipe yaitu batuan beku, batuan sedimen dan batuan metamorf. Pembentukan ketiga tipe batuan mengalami siklus seperti pada Gambar 9.

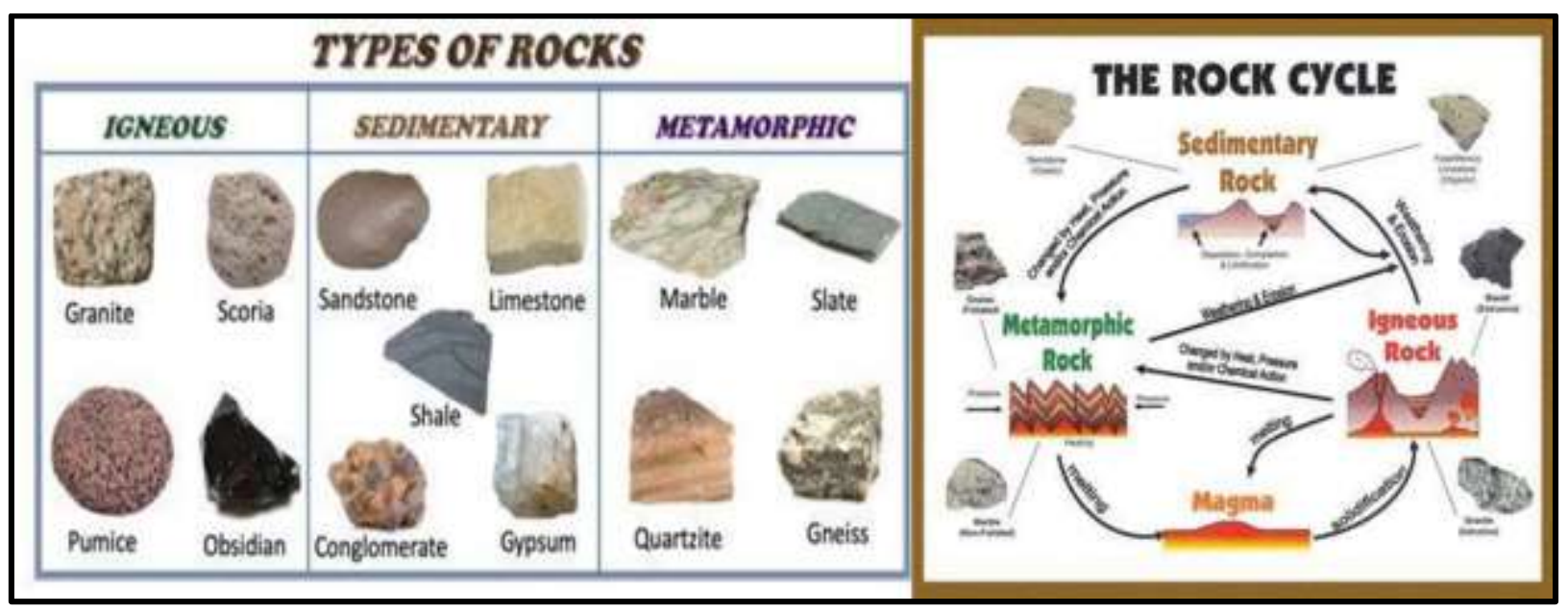

Gambar 9. Tipe dan Siklus Batuan

\subsubsection{Batuan Beku}

Batuan beku terbentuk dari kristalisasi magma saat mengalami penurunan temperatur ketika mengalami evolusi (Gambar 10).

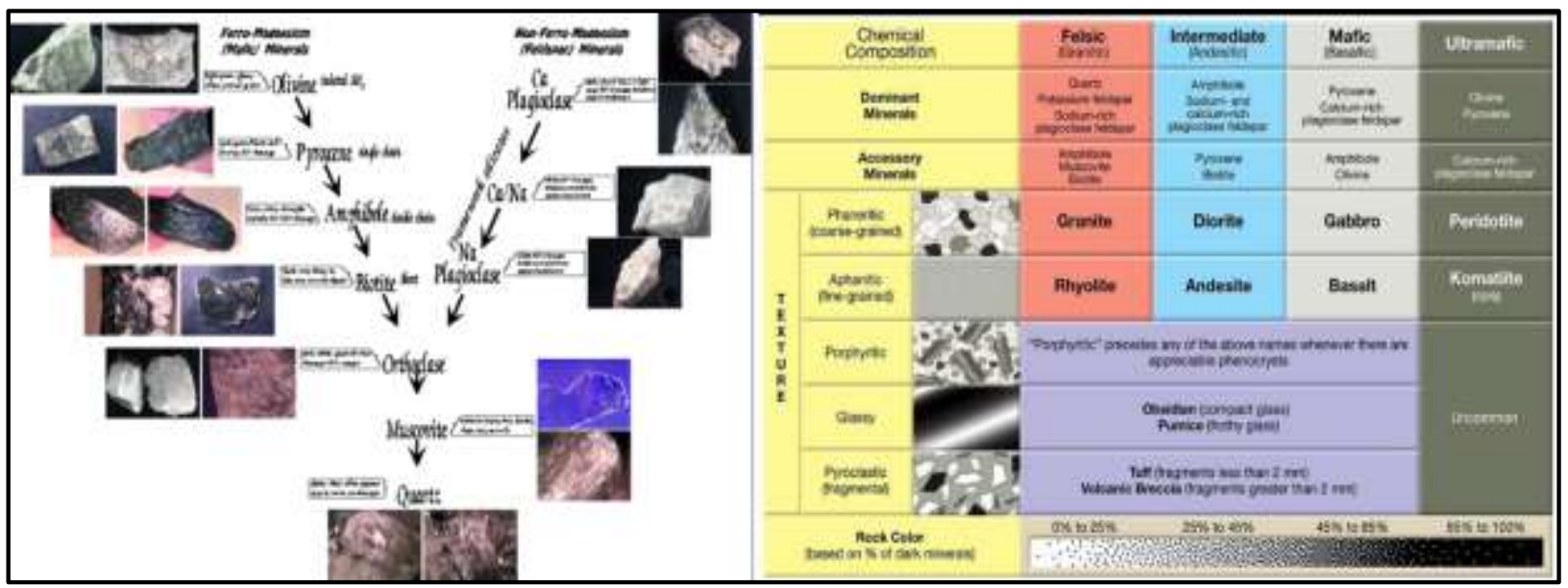

Gambar 10. Seri batuan yang terbentuk pada temperature dan kedalam yang besar hingga yang di dekat permukaan kerak bumi.

\subsubsection{Batuan Sedimen}

Batuan sedimen terbentuk dari lithifikasi batuan yang telah terbentuk sebelumnya pada permukaan setelah mengalami pelapukan, transportasi, dan diagenesis (Gambar 11) 


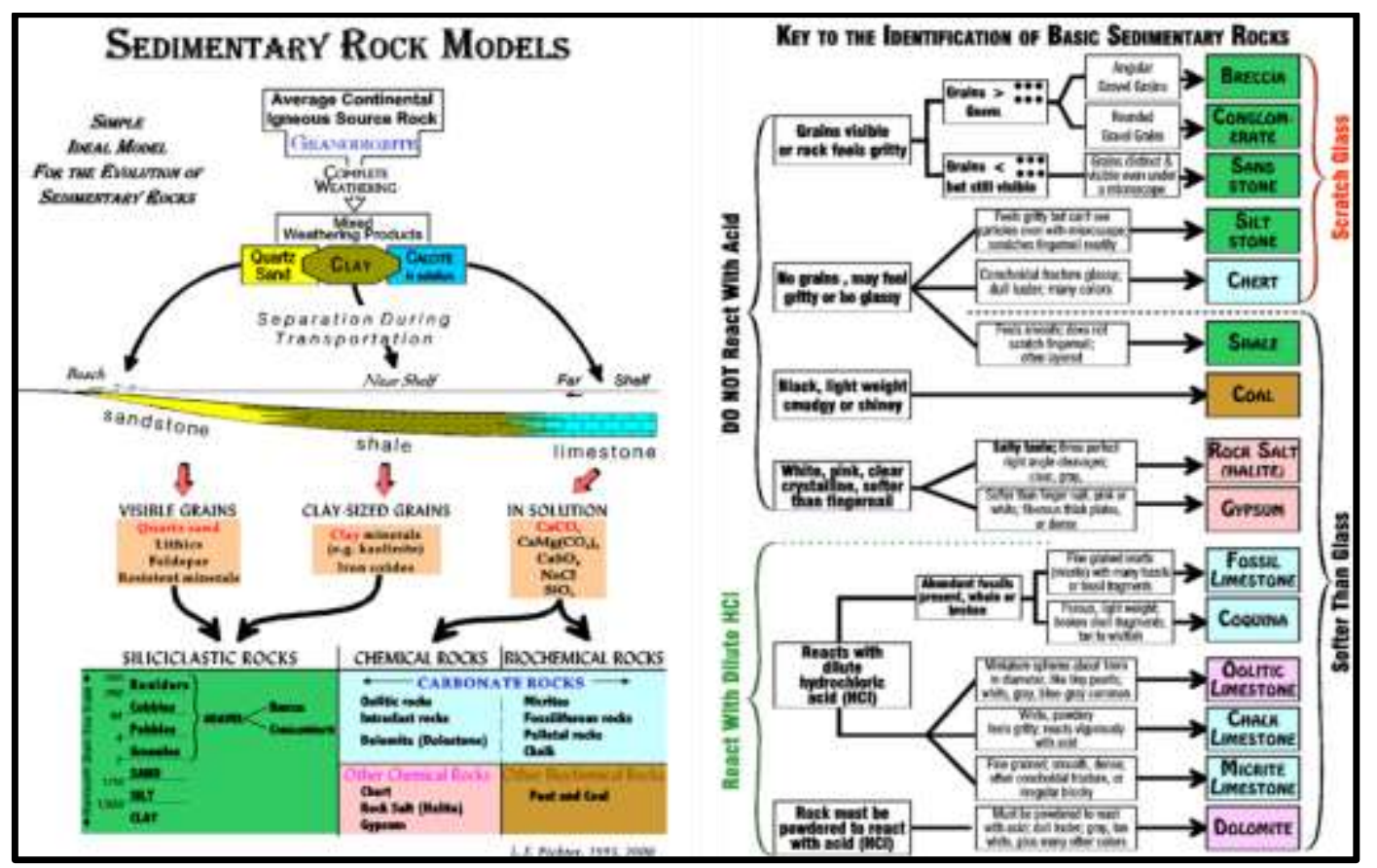

Gambar 11. Pembentukan Batuan Sedimen Dan Tahapan Identifikasi Batuan Sedimen

\subsubsection{Batuan Metamorf}

Batuan metamorf terbentuk karena adanya peningkatan temperature dan tekanan terhadap batuan yang telah terbentuk sebelumnya, sehingga mengalami perubahan mineralogi, tekstur dan struktur (Gambar 12).

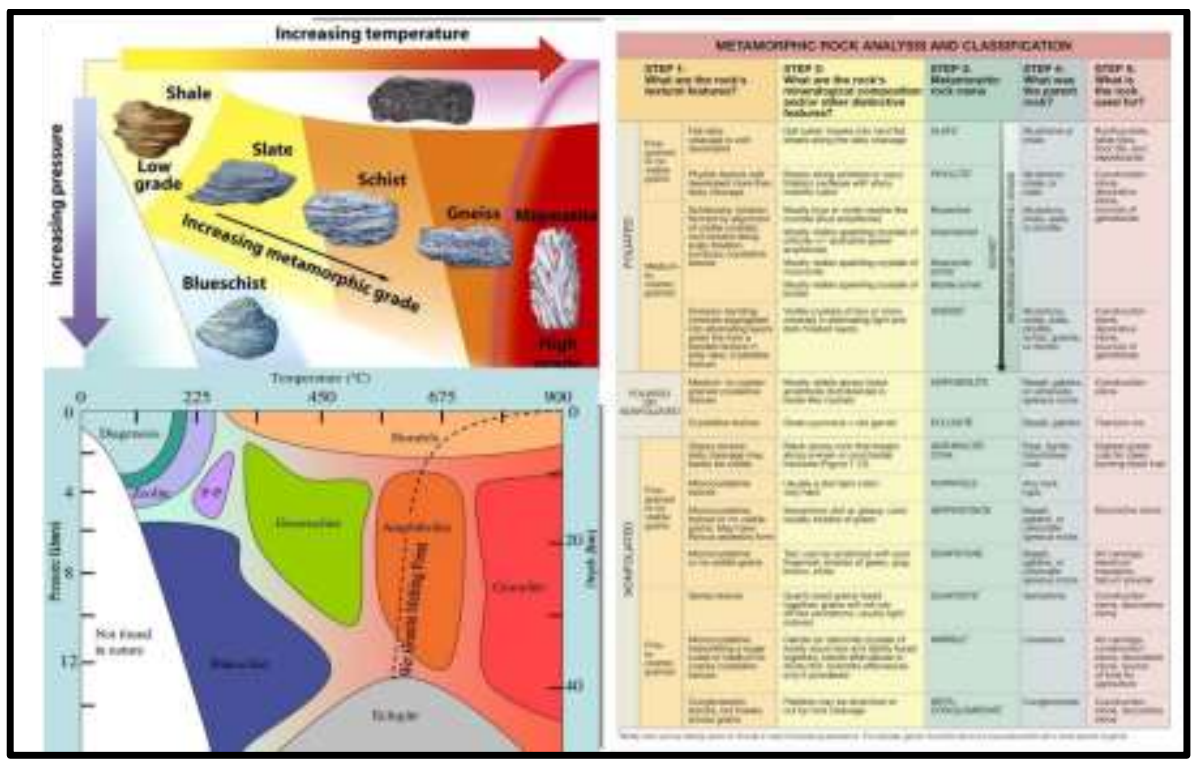

Gambar 12. Jenis Dan Facies Batuan Metamorf Serta Klasifikasinya.

\section{Kesimpulan}

Kontribusi mendasar yang dapat diberikan kepada mitra yaitu guru dan siswa SMA Negeri 8 Kabupaten Gowa adalah peningkatan kapasitas keilmuan di bidang kebumian bagi guru-guru 
geografi selaku pembina OSN bidang kebumian. Dampak positif pada siswa yang telah mempunyai motivasi dan kepercayaan diri untuk mengikuti pembinaan dan siap berkompetisi pada OSN bidang kebumian pada tingkat kabupaten dan nasional. Metode SCL memudahkan siswa untuk mengidentifikasi berbagai materi olimpiade sain nasional bidang kebumian yang terdiri dari mineral, batuan, struktur, fosil, geomorfologi dan pembacaan peta geologi.

\section{Ucapan Terima Kasih}

Penulis mengucapkan terima kasih kepada Dinas Pendidikan Provinsi Sulawesi Selatan dan Kepala Sekolah SMA Negeri 8 Gowa atas kerjasama yang sangat baik dalam pelaksanaan kegiatan pengabdian ini. Terima kasih pula kami ucapkan kepada Fakultas Teknik yang telah memberikan hibah Labo-based education tahun 2019. Kepada anggota LBE Departemen Teknik Geologi, terima kasih atas partisipasinya dalam menyiapkan sampel yang digunakan dalam kegiatan pengabdian ini.

\section{Daftar Pustaka}

Anwar, A. I., Prabandari, Y.S., Emilia, O. (2013). Motivasi dan Strategi Belajar Siswa dalam Pembelajaran berbasis Collaborative Learning di Fakultas, Kedokteran Gigi, Universitas Hasanuddin, Jurnal Pendidikan Kedokteran Indonesia, Vol. 2 No. 3, 233-239

Brady, J. B., Mogk, D. W dan Perkins, D., 2011, Teaching mineralogy, Mineralogical Society of America, 406 hal.

Dana, J. D., (2008), Manual of Mineralogy, Enl New Re edition, Merchant Books, 456 hal.

Deer, W., Howie, R.A. dan Zussman, J. (1996. Introduction to the Rock-Forming Minerals, 2nd edition, Prentice Hall, 712 hal.

Irfan, U.R. (2016). Mineral Barit Daerah Sangkaropi, Kabupaten Toraja Utara, Indonesia, Prosiding Seminar Ilmiah Nasional Vol 1, ISBN: 978-979-17225-9-92015, Fakultas Teknik Universitas Hasanuddin, Gowa, pp. TG8-1/10, 03 - 04 September 2015.

Kementerian Pendidikan dan Kebudayaan, 2019, Pedoman Olimpiade Sains Nasional, Direktorat Jenderal Pendidikan Dasar dan Menengah, Direktorat Pembinaan Sekolah Menengah Atas, http://olimpiade.psma.kemdikbud.go.id/index/panduan/2019/PedomanOSN2019.pdf

Nur, I., Irfan, U.R., Sufriadin and Ilyas, A., 2016, Mineralogical and geochemical characteristics of the volcanogenic massive sulphide deposits in Sangkaropi district, North Toraja, Indonesia, The $3^{\text {rd }}$ International Symposium on Smart Material and Mechatronics 2016,Fakultas Teknik Unhas, Gowa, 15-17 November 2016. 